\title{
Compratative Stady on Pre-Competition Anxiety between National and State Level Women Athletes
}

\author{
Biswabandhu Nayek ${ }^{1}$ Dr. Kallol Chatterjee ${ }^{2}$ \\ 1 (Guest Lecturer, Dept Of Physical Education Sree Chaitanya College Of Commerce, W.B, India) \\ 2 (Asst. Professor, P.G.G.I.P.E, Banipur North 24 Pgs. West Bengal, India)
}

\begin{abstract}
The purpose of the study was to find out pre-competition anxiety between national and state level women athletes. Due to the fact that during competition athletes' mental state greatly affects their stamina explosion, which finally influence the result of final competition. Anxiety in sports is considered as an important issue for many athletes. It refers to a sort of nervous and fear emotion formed by frustration of self-esteem and self-confidence, or increasing of the sense of failure and guilty, which is resulted by the threat from being unable to achieve goals or to overcome obstacles at the right time. For the purpose of the study the subjects were selected randomly from $63^{\text {rd }}$ State Athletic Championships of West Bengal to measure the pre-competition anxiety by a questionnaire Sport Competition Anxiety Test (SCAT) developed by Rainer Marten. 25 national level and 25 state level women athletes selected randomly from the said Athletic Championships. To find out pre-competition anxiety between national level and state level women athletes ' $t$ ' test was applied. The result showed that there was significant difference on pre-competition anxiety between national level and state level women athletes. The national level women athletes had less pre-competition anxiety than the state level women athletes.
\end{abstract}

Key words: Pre-competition anxiety, National level women athletes, State level women athletes.

\section{Introduction}

Sports is littered with broken dreams of those whose performance collapsed when they are most needed to be in control of themselves and focus on the task at hand. It is not uncommon to see athletes "freeze" in big games or moments or commit unexplainable error in the course of their performance. When athletes do not perform well in relation to their abilities, nervousness in anticipation of the sporting challenges could be the root cause of anxiety.

Track and field competition has always been regarded as "mother of sports", for it is the foundation for the other sporting events (John and Paul, 1993). What's more, sprint is a fundamental event in track and field sports, with very significant meaning and role to the training of other sporting events (Mangan, 2009).

Anxiety refers to a sort of nervous and fear emotion formed by frustration of self-esteem and selfconfidence, or increasing of the sense of failure and guilty, which is resulted by the threat from being unable to achieve goals or to overcome obstacles (Akbar et al., 2011). Anxiety can have a devastating effect on the performance of an athlete. No matter how much talent or skill one may have, he will never perform at his or her best if he or she lives in fear before every event.

The problem of pre-competitive anxiety is one of the most pressing problems in modern sports psychology. It has been recognized for many years that psychological factors, in particular anxiety, play an important role in competition and in competitive sports, every athlete experience fear before, during and after events (Lizuka, 2005). Anxiety could make even the world most successful athlete feel nervous. According to Moran (2004), factors such as fear of failure and lack of confidence induce feeling of anxiety in athletes. Anxiety is like worry; it is an unpleasant emotion that most athletes feel at sometimes when they are faced with challenges.

Researcher took up this study to compare the Pre Competitive anxiety between the Players who represent the West Bengal in national level track and field competition, and the Players who represent their respective District in state level but could not qualify for the National Championship.

The purpose of the study was to compare the differences on pre-competition Anxiety between women National and State level Athletes.

Mr. PARESH D. TREVADI (Research Scholar, Singhania University, Rajasthan)Dr. VIPUL H. UPIDHAYA (Research Scholar, Singhania University, Rajasthan) "A Comparative Study of Sports Competition Anxiety Between Male and Female Weight Lifters of Gujarat" They were found significant result.

N. Esfahani( Alzahra University) and H. Gheze Soflu(Gonbade Kavoos University) "The Comparison of Pre-Competition Anxiety and State Anger between Female and Male Volleyball Players" They also found significant result. 
Jamilah Ahmad Radzi ( Faculty of Sport Science and Recreation Universiti Teknologi Mara, UiTM Shah Alam ) Sarina Md Yusof (Faculty of Sport Science and Recreation Universiti Teknologi Mara, UiTM Shah Alam ) Abdul Aziz Zakaria (Faculty of Sport Science and Recreation Universiti Teknologi Mara, UiTM Shah Alam) "PRE-COMPETITION ANXIETY LEVELS IN INDIVIDUAL AND TEAM SPORTS ATHLETES" They also found significant result.

Mr. Amit K. Gamit. (Research Scholar CMJ Universit) "A Comparative Study of Sports Competition Anxiety. Between Male and FemaleCricket. Players of Gujarat"He also found significant result.

Using the right techniques such as visualization, goal setting, cognitive restructuring, developing self confidence and focusing on what you can control rather than what you control cannot will help athletes free from pre-competitive anxiety. For the Coaching and teaching should provide more and more competition within the frame work of practice and training inculcate anxiety and stress free behavior

\section{Methodology}

For the purpose of the study 25 female national level athletes, who participated at national level Athlets competition as a representative of West Bengal and 25 female state level athletes, who participated in state level Athletic competition as a representative of their districts but could not qualify for the National level Championship were selected randomly from $63^{\text {rd }}$ West Bengal state Athletic Championships. The age of the subjects ware ranged between 14 to 24 years.

To compare the pre competition anxiety between the National and the state level players the data were collected by using Sport Competition Anxiety Test (SCAT) questionnaire, developed by Rainer Marten.

Student's ' $t$ ' test at 0.05 level of significance was applied to calculate the significance of difference between national and State level Women Athletes.

\section{Finding}

\section{Table-1}

Significance of Differences of Mean, Standard deviation and ' $\mathrm{t}$ ' test on pre-competition Anxiety between women national and state level Athletes.

\begin{tabular}{|c|c|c|c|}
\hline groups & mean & std- deviation & t-ratio \\
\hline national level athlete & 17.6 & 4.01 & $2.38^{*}$ \\
\hline state level athlete & 20.08 & 3.16 & \\
\hline
\end{tabular}

Table-1 shows that the mean and standard deviation and ' $t$ ' test of Women national level and state level Athlete on pre-competition Anxiety. Mean and standard deviation of national level Track and Field event player has been found 17.6 \pm 4.01 and $20.08 \pm 3.16$, the mean and standard deviation of state level Track and Field event player. The ' $t$ ' value of pre -competition Anxiety is $2.38 *$ this is significant.

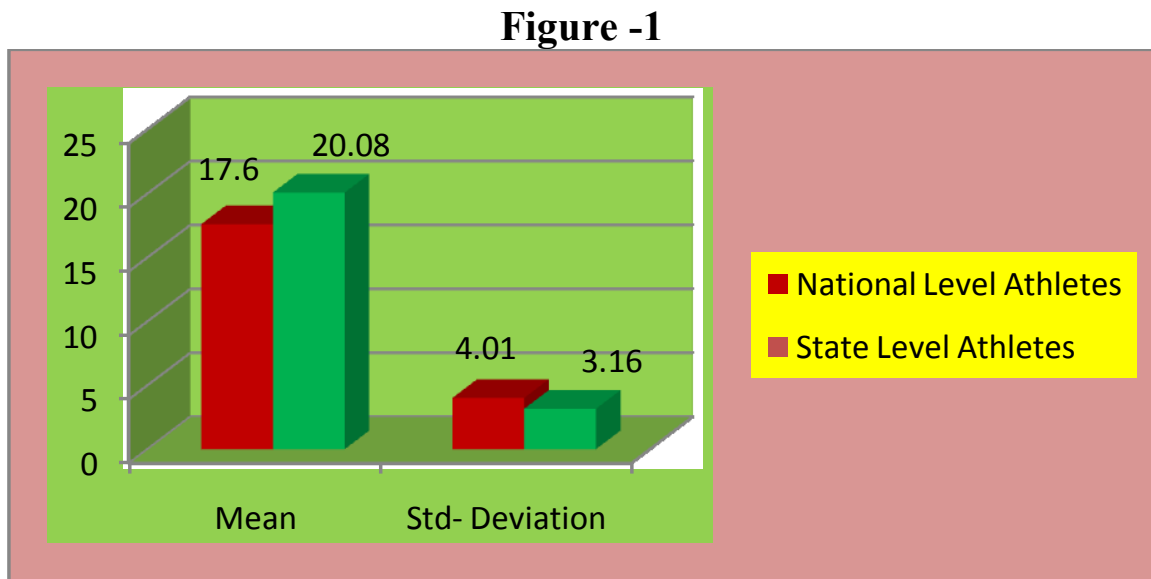

Graphical representation of Mean \& SD on Pre-Competition Anxiety between women national \& State Level Athletes.

The above table reveals that significant mean difference was found between women national and State level Athletes in relation

to pre-competition anxiety as against the Calculated value of $\mathrm{t}=2.38$ is greater than the tabulated $\mathrm{t}_{05}(48)=2.00$ 


\section{Discussion of finding}

Anxiety plays a paramount role in sports. It is the challenge in sports participation which produces anxiety. How an athlete handles the anxiety determines how successful he would be. Anxiety may be a positive motivating force or it may interfere with successful performance in sports events. The degree of anxiety also varies with a number of different conditions. Anxiety is likely to be greater in higher competitive sports than in relatively non competitive sports, because in the competitive sports, participants are expected to win a great demands are made up on them to succeed.

It is revealed from the above findings that the Women state level athletes possessed more precompetition Anxiety than the Women national level athletes.

This study highlighted the anxiety levels by utilized both psychological and physiological measures of anxiety as the competition approached among women national and state level athletes. The mean for precompetition Anxiety scores shown higher in state level athletes compared to national level athletes but in case of SD national level women athletes shows higher result.

With the Sport Competition Anxiety Investigation Form (CSAI- 2) compiled by Fu (1997, 1999) has conducted a series of researches concerning the relationship between Chinese university athletes' precompetition anxiety and competition performance, as well as the correlativity between high-level athletes' precompetition anxiety and competition performance (Fu, 1997, 1999$)$.

A comparison of national and state athletes revealed several significant differences. National track and field event athletes reported higher self-confidence intensity, win orientation, and ethnic identification scores compared to state track and field athletes. The previous literature showing increased self-confidence levels associated with higher ethnic identity among African Americans (Martinez \& Dukes, 1997) may also partially explain the higher win orientation scores among this population.

Competitive anxiety is one of the factors to decrease athletes' performance (Esfahani \& Soflu., 2010). Feelings of tension, thinking of upcoming events in their mind, nervousness, worry and involved in physiological changes such as increased in heart rate response are common response for the athletes prior to the competition (Hackfort \& Spielberger, 1989). Some athletes also involved with the feelings of fear, unhappiness, guilt, discouragement, and focus distraction (Cerin, 2003; Kais \& Raudsepp, 2005).

The national level players are more experienced and have adjustable ability with the environment and situation before competition. They are able to control their emotion and anxiety. Their nutritional status, blended demand with training for skill development in their training schedule and previous record in competition increase their confident level before competition. These have been reflected in the result for significant differences.

Douglas et al (2006) stated that the major sources of pre-competitive anxiety include: fear of failure, thinking too much on what people may say about the performance, and lack of confidence. They concluded however, that pre- competitive anxiety is dependent upon factors such as: skill level, experience and general level of arousal in daily activities. In case of state athletes they are not too much experienced and exposed to competition like elite athletes.

\section{Conclusion}

Based on the findings and within the limitation of the present study, following conclusions were drawn:-

- Women state level athletes, are much more Prone to pre-competitive anxiety due to fear of failure, thinking too much on what people may say about the performance, and lack of confidence, skill level, experience and general level of arousal in daily activities

- Women national level athletes are subjected to less pre-competitive anxiety due to more experience and adjustable ability with the environment and situation before competition, control their emotion and anxiety, their training schedule and previous record in competition and practice.

\section{Acknowledgement}

It is real pleasure that, I record my indebtedness to my teacher Dr.A.K.Bose for his counsel and guidance during the preparation of this research paper. I am also grateful to Dr. D.P.Sahu for all the suggestions offered an encouragement given to me. My thanks are due to all the students who acted as a subject for the study. With their voluntary and wholehearted support could not have been completed. Specially thanks to all the coches of national level and state level athletes 
Journal Papers:

\section{References}

[1]. Duda, J. y Gano-Overway, L. (1996). 'Anxiety in Elite Young Gymnasts: Part I - Definitions of Stress and Relaxation'. Electronic document retrieved on March 10, 2012

[2]. Hale, B. \& Witehouse, A. (1998). 'The effects of imagery-manipulated appraisal on intensity and direction of competitive anxiety'.

[3]. Hanton, S. \& Jones, G. (1994). 'Antecedents and levels of intensity and direction dimensions of state anxiety in elite and nonelite swimmers'. Journal of Sports Science, 12

[4]. Hanton, S, Neil, R. Mellalieu, D. \& Fletcher, D. (2008). ' Competitive experience and performance status: An investigation into multidimensional anxiety and coping'. European Journal of Sport Science, 8 ,

[5]. Jones, G. (1991) ' Recent developments and current issues in competitive anxiety in sport'. The Sport Psychologist, 4,

[6]. Jones, G. (1995) 'More than just a game: Research developments and issues in competitive anxiety in sport'. British Journal of Psychology, 86,

[7]. Jones, G. \& Hanton, S. (2001) ' Pre- competitive feeling states and directional anxiety interpretations'. Journal of Sports Sciences, 19, 385-395.

[8]. Jones, G. Swain, A. \& Hardy, L. (1993) 'Intensity and dimension directions of competitive state anxiety and relationships with performance'. Journal of Sport Sciences, 11, 525-532.

[9]. Kais, K. \& Raudsepp, L. (2005) ' Intensity and direction of competitive state anxiety, self-confidence and athletic performance'.

[10]. Krane, V. \& Williams, J. (1987) ' Performance and somatic anxiety, cognitive anxiety and confidence change prior to competition'. Journal of Sport Behavior, 10, 47-56.

[11]. López-Walle, J., Ramírez, B., Tristán, J., Pérez, J., y Ceballos, O. (2011) ‘ Confirmatory factor analysis of the Competitive State Anxiety Inventory in Mexican university athletes'.

[12]. Lundqvist, C., Kenttä, G. \& Raglin, J. S. (2011). 'Directional anxiety responses in elite and sub-elite young athletes: Intensity of anxiety symptoms matters'. Scandinavian Journal of Medicine and Science in Sports, 21,

[13]. Martens, R., Vealey, R. \& Burton, D. (1990) ' Competitive anxiety in sport. Champaign, IL, United States': Human Kinetics Publishers.

[14]. Mellalieu, S., Hanton, S. \& O'Brien, M. (2004) ' Intensity and direction of competitive anxiety as a function of sport type and experience'. Scandinavian Journal of Medicine and Science in Sports, 14,

[15]. Ntoumanis, N. \& Biddle, S. (1997) 'The relationship between competitive anxiety, achievement goals, and motivational climates'.

[16]. Yao Jiwei, Yang Yongliang, Xie Xiang, Xu Wenxin, Ding Xiushi ,2013) 'A Neural Network Model for the Correlation between Sprinters' Pre-competition Anxiety and Competition Performance' Research Journal of Applied Sciences, Engineering and Technology 6(1): 75-81,

[17]. Anagnostopoulos Vasiliki 'EXPLORING THE EFFECTS OF ETHNICITY ON PRE-COMPETITION ANXIETY AND SELF-CONFIDENCE IN COLLEGIATE TRACK AND FIELD ATHLETES

[18]. Amasiatu, Athan. N. \& Uko, Ime Sampson (2013) 'COPING WITH PRE-COMPETITIVE ANXIETY IN SPORTS COMPETITION'.

[19]. Dr. Sharma Kalpana , Kathuria Shubhra(2012 ) 'Sports Competitions: Pre-Competition Anxiety - Does It Matters' Journal of Education and Practice Vol 3, No.9, John, S.R. and E.T. Paul, (1993). 'Anxiety and performance in track and field athletes: A comparison of the inverted-U hypothesis with zone of optimal function theory'. Personal. Indiv. Differ., 14(1): 163171Mangan, M., (2009) 'Dietary intake of senior athletes participating in the 2008 southeastern masters track and field meet'. J. Am. Diet. Assoc., 109(S9): A24.

[20]. Siwach Rajesh Kumar \&Jaipal(2013 ) 'A STUDY OF PRE-COMPETITIVE ANXIETY OF ARCHERS IN

[21]. RELATION TO THEIR PERFORMANCE' International journal of research pedagogy and technology in education and movement sciences (ijems) vOL.01

Books:

[22]. Verma J Prakash "A TEXT BOOK ON SPORTS STATISTICS"

[23]. Barry, L.; Johnson J. \& Nelson, K. (1988) ' Practical Measurements for Evaluation in Physical Education'. New Delhi: Surjeet Publication 